\title{
The influence of microorganisms and of stress on the chick's requirement for pantothenic acid
}

\author{
BY EVA A. LATYMER AND MARIE E. COATES \\ National Institute for Research in Dairying, Shinfield, Reading RG2 9AT
}

(Received 16 May 1980 - Accepted 5 September 1980)

\begin{abstract}
1. The responses of germ-free (GF) and conventional (CV) chicks to suboptimal amounts of dietary calcium pantothenate $(\mathrm{CaPa})$ were compared. At the lower levels of supplementation the signs of deficiency were more severe in the CV chicks.

2. Calculations based on mean body-weights of chicks given graded dietary supplements of calcium pantothenate ( $\mathrm{CaPa}$ ) in both environments showed that, to achieve the same body-weight and freedom from signs of deficiency, the GF birds required only approximately two-thirds the amount of $\mathrm{CaPa}$ as was needed by corresponding $\mathrm{CV}$ birds.

3. Increasing the dietary supplement of CaPa resulted in increased contents of $\mathrm{PaA}$ in the livers. GF birds had more $\mathrm{PaA}$ per liver than their $\mathrm{CV}$ counterparts. In both instances the effect was due to the larger liver size. Concentration of $\mathrm{PaA}$ in the liver was not affected by dietary supplement nor by the environment.

4. CV birds were deemed to be under greater stress than GF birds because their adrenal glands were heavier and contained less cholesterol.

5. CV chicks deliberately stressed by injections of adrenocorticotrophic hormone had heavier adrenals with lower cholesterol contents than unstressed controls, but the condition was not altered by increasing the dietary supply of $\mathrm{CaPa}$.
\end{abstract}

In studies with germ-free (GF) and conventional (CV) chicks Coates et al. (1968) showed that substantial amounts of most vitamins of the B complex were synthesized by microbial action in the lower gut. Nevertheless the effects of deficiency were as severe in the CV as in the GF birds, implying that the synthesised vitamins were not absorbed. On a diet deficient in pantothenic acid $(\mathrm{PaA})$ mortality was higher in the $\mathrm{CV}$ environment, and the amount of $\mathrm{PaA}$ in the livers was significantly less, which led the authors to suggest that the requirement for $\mathrm{PaA}$ was increased in the presence of the gut microflora. Since coenzyme A (CoA) has a role in adrenocortical function, the activity of which is increased by stress, they postulated that the apparently greater demand for $\mathrm{PaA}$ might be the result of stress imposed by the microbial burden. The experiments now reported were done to verify the higher requirement for $\mathrm{PaA}$ by $\mathrm{CV}$ birds and to investigate the hypothesis that it was brought about by stress.

\section{MATERIALS AND METHODS \\ Chicks}

Chicks were the progeny of the Institute's specified-pathogen-free flock of Rhode Island Red cocks $\times$ Light Sussex hens. For the experiments with GF birds clean eggs were incubated in the usual way for $18 \mathrm{~d}$, then disinfected externally with peracetic acid vapour (Harrison, 1969) and taken into sterile Gustafsson stainless steel isolators where they were left to hatch. Their corresponding CV controls were taken from the same batch of eggs but after the disinfection process were returned to the incubator to hatch. The chicks were housed in groups of four in cages with wire-mesh floors, either inside the isolators or in a room in which temperature, lighting and humidity could be matched to the conditions in the isolators. In the last experiment, using CV chicks only, groups of ten birds were maintained in electrically-heated tiered brooders in a standard brooder room. In all 
experiments the birds were distributed so that initial body weights and sexes were as evenly disposed as possible among the experimental treatments. Sterility checks were performed on the GF birds soon after hatching and at the end of the experiments.

\section{Diets}

The basal diet of purified ingredients had the following composition $(\mathrm{g} / \mathrm{kg})$ : maize starch 596.5 , casein (low vitamin, Calbiochem Ltd, Bishops Stortford) 180.0, gelatin 100.0, L-cystine 3.0, choline chloride $1 \cdot 5$, myo-inositol 1.0, maize oil 50.0 , salt mixture $60 \cdot 0$, vitamin mixture in giucose 8.0. The salt mixture provided (/kg diet): $\mathrm{CaCO}_{3} 17 \cdot 1 \mathrm{~g}$, $\mathrm{CaHPO}_{4} \cdot 2 \mathrm{H}_{2} \mathrm{O} 17 \cdot 1 \mathrm{~g}$, $\mathrm{KH}_{2} \mathrm{PO}_{4} 13.3 \mathrm{~g}, \mathrm{NaCl} 8.67 \mathrm{~g}, \mathrm{MgSO}_{4} \cdot \mathrm{H}_{2} \mathrm{O} 2.67 \mathrm{~g}, \mathrm{FeSO}_{4} .7 \mathrm{H}_{2} \mathrm{O} 670 \mathrm{mg}, \mathrm{MnSO}_{4} .4 \mathrm{H}_{2} \mathrm{O}$ $270 \mathrm{mg}, \mathrm{ZnSO}_{4} .7 \mathrm{H}_{2} \mathrm{O} 130 \mathrm{mg}, \mathrm{KI} 37 \mathrm{mg}, \mathrm{CuSO}_{4} .5 \mathrm{H}_{2} \mathrm{O} 16 \mathrm{mg}$. Vitamin supplementation was higher than normal to allow for possible losses during sterilization of the diet. The vitamin mixture provided $(/ \mathrm{kg}$ diet): pteroylmonoglutamic acid $6.0 \mathrm{mg}$, thiamin hydrochloride $12.0 \mathrm{mg}$, pyridoxin hydrochloride $16.0 \mathrm{mg}$, riboflavin $24.0 \mathrm{mg}$, nicotinic acid $160.0 \mathrm{mg}$, biotin $0.8 \mathrm{mg}$, cyanocobalamin $80 \mu \mathrm{g}$, retinol $20.4 \mathrm{mg}$ (as Rovimix A-500, Roche Products, Dunstable, Beds), menaphthone $20 \mathrm{mg}$, DL-tocopheryl acetate $40 \mathrm{mg}$ and cholecalciferol $0.16 \mathrm{mg}$. The last three items were dissolved in the maize oil. Where necessary calcium pantothenate $(\mathrm{CaPa})$ was included at doses between 0 and $6.25 \mathrm{mg} / \mathrm{kg}$ diet. After mixing the diets were granulated by moistening with water, passing through a $5 \mathrm{~mm}$ mesh sieve then drying on stainless-steel trays in a current of warm air at $42^{\circ}$. For Expts 1-4 the diets were sterilized by gamma-radiation at $5 \mathrm{Mrad}$, and the sterilized diets were given both to the GF chicks and their CV controls.

\section{Analytical methods}

Preparation and storage of samples. At the end of the experiments the chicks were killed by cervical dislocation and the required tissues immediately removed, blotted and weighed. Adrenals were plunged into liquid nitrogen and stored at $-20^{\circ}$ until analysed. Livers were also rapidly cooled in liquid $\mathrm{N}_{2}$ then cut into smaller pieces and maintained ice-cold while being homogenized for $3 \mathrm{~min}$. The homogenized samples were divided between a number of vials and kept at $-20^{\circ}$ until analysed.

Microbiological assays. $\mathrm{PaA}$ activity was measured by a microbiological assay using Lactobacillus plantarum strain NCDC 82, ATAA 8014 (Bird, 1963). Homogenized liver samples were extracted with $0.14 \mathrm{M}$-sodium phosphate buffer at $\mathrm{pH} 6.6$ for $10 \mathrm{~min}$ at $115^{\circ}$, cooled and adjusted to $\mathrm{pH} 4.6$ then filtered and readjusted to $\mathrm{pH}$ 6.8. Free $\mathrm{PaA}$ was determined in the extracts. Total (free plus bound) $\mathrm{PaA}$ was determined after treatment of the homogenate with alkaline phosphatase and chick liver enzyme as described by Barton-Wright (1963).

Determination of cholesterol. Cholesterol was determined in homogenates of adrenals by the method of Zlatkis et al. (1953).

Experimental design. Four experiments were done to compare the response of chicks in a GF or CV environment to suboptimal graded dietary supplements of CaPa. The experimental diets were fed from the first day of age. The birds were weighed at weekly intervals and examined daily for signs of deficiency, namely, lesions at the corners of the mouth and on the feet, incoordinated movements and death. They were killed during the fourth week of life, when the signs of deficiency among those on the lower supplements were severe but while most of the birds were still surviving the treatment. In Expt 3 the livers were analysed for bound and total $\mathrm{PaA}$. In Expt 4 cholesterol was measured in the adrenal glands. The dietary supplements of $\mathrm{CaPa}$, the duration of the experiment and the number of birds per treatment (in parentheses) were as follows:

Expt 1. 0, 2.67, 4.0 and $6.0 \mathrm{mg} / \mathrm{kg} 25 \mathrm{~d}(4)$,

Expt 2. 0, 2.67, 4.0 and $6.0 \mathrm{mg} / \mathrm{kg} 25 \mathrm{~d}(4)$, 
Expt 3. $3 \cdot 02,3 \cdot 62,4 \cdot 34,5 \cdot 21$ and $6 \cdot 25 \mathrm{mg} / \mathrm{kg} 21 \mathrm{~d}(16)$,

Expt 4. 2.67 and $4.0 \mathrm{mg} / \mathrm{kg} 25 \mathrm{~d}$ (24).

Expt 5 was done with CV birds only, to investigate a possible relationship between stress and the chick's requirement for $\mathrm{PaA}$. Four groups of ten chicks received the basal diet supplemented with either 2.67 or $4.0 \mathrm{mg} \mathrm{CaPa} / \mathrm{kg}$. Half the birds on each dietary treatment were 'stressed' by intramuscular injection three times weekly of a long-acting preparation of adrenocorticotrophic hormone (ACTH; Corticotrophin gelatin injection, B.P., Armour Pharmaceutical Co. Ltd, Eastbourne) at the rate of 120 i.u. $/ \mathbf{k g}$ body-weight. The remaining half of the chicks were injected at the same time with similar volumes of physiological saline ( $9 \mathrm{~g}$ sodium chloride/l). The experiment lasted for $24 \mathrm{~d}$, when the birds were killed and cholesterol determined in the adrenals.

Statistical treatment of results. In Expts 1 and 2 analysis of variance was performed on body-weights of individual chicks and in Expt 3 on mean body-weights of cages of four birds. In Expt 3 the livers from all birds of the same sex within a cage were combined before further treatment. In Expts 4 and 5 pairs of adrenal glands from individual chicks were analysed and the results averaged to give two values for each cage, one for each sex. Similarly the body-weights, liver weights and microbiological assay results were averaged to give two values per cage. These average values were subjected to analysis of variance, the variation being divided into that between and within cages. The variation between cages was further divided into variation between environment (GF and CV), treatments (dietary supplements of $\mathrm{CaPa}$ ) and the pooled residual variation between cages. This residual variation was used to test the significance of treatment effects and to calculate the standard errors of differences between treatment means which are given in the figures and tables. The variation within cages was divided into variation due to sex, sex $\times$ dietary treatment interaction and the pooled residual variation within cages. This second residual variation was used to test the significance of sex $\times$ diet effects. In the event, a few significant effects of sex were detected but as they were small in relation to the effects of the experimental treatments, and the sexes were evenly distributed, they have not been recorded here.

The requirement for PaA of chicks in the GF and $\mathrm{CV}$ environment was assessed from their responses to the graded dietary supplements of $\mathrm{CaPa}$. Dose-response curves were constructed by plotting the mean body-weights $v$. logarithm of the dose of $\mathrm{CaPa}$. If the requirement in both environments was the same the curves would be expected to coincide, but since they did not a quantitative estimate of the difference between them was made by applying the method of biological assay of $\mathrm{PaA}$ described by Coates et al. (1950). The curve constructed from the values from GF chicks was regarded as the standard and that from the mean weights of the CV chicks as a test curve. They were checked for linearity and parallelism, the common slope was calculated and the relative potency of the diet for CV chicks was estimated as the difference between the logarithmic doses of $\mathrm{CaPa}$ that produced a similar response in the two environments. Limits of error were calculated as recommended by the British Standards Institution for the biological assay of vitamin $D_{\mathbf{3}}($ British Standards Institution, 1940).

\section{RESULTS}

Sterility checks

In both Expts 1 and 2 an isolator became contaminated so that only one group of four chicks on each experimental treatment completed the test. In Expts 3 and 4 no contaminations were detected throughout the whole experimental period.

\section{Incidence of deficiency}

The mean body-weights, mortality and numbers of birds with signs of PaA deficiency are shown in Table 1. Body-weights were higher in the GF environment except at the higher 
Table 1. Mean body-weights, relative numbers of birds showing signs of deficiency and mortality in groups of germ-free $(G F)$ and conventional ( $C V$ ) chicks given suboptimal amounts of dietary calcium pantothenate $(\mathrm{CaPa})$

(Duration of tests was 25, 25 and $21 \mathrm{~d}$ for Expts 1, 2 and 3 respectively)

\begin{tabular}{|c|c|c|c|c|c|c|c|c|}
\hline \multirow[b]{2}{*}{ Expt no. } & \multirow{2}{*}{$\begin{array}{c}\text { No. of } \\
\text { birds per } \\
\text { treatment }\end{array}$} & \multirow{2}{*}{$\begin{array}{l}\text { Dose of } \\
\text { CaPa } \\
(\mathrm{mg} / \mathrm{kg})\end{array}$} & \multicolumn{2}{|c|}{$\begin{array}{l}\text { Body-wt } \\
\text { (g) }\end{array}$} & \multicolumn{2}{|c|}{$\begin{array}{l}\text { No. of birds showing } \\
\text { signs of } \\
\text { deficiency }\end{array}$} & \multicolumn{2}{|c|}{$\begin{array}{c}\text { No. of } \\
\text { dead birds }\end{array}$} \\
\hline & & & GF & $\mathrm{CV}$ & GF & $\mathrm{CV}$ & GF & CV \\
\hline 1 & 4 & 0 & 108 & 90 & $0 / 3$ & $2 / 2$ & $1 / 4$ & $2 / 4$ \\
\hline 2 & 4 & 0 & 112 & 95 & $0 / 3$ & $2 / 2$ & $1 / 4$ & $2 / 4$ \\
\hline 1 & 4 & 2.67 & 204 & 157 & $0 / 3$ & $3 / 3$ & $1 / 4$ & $1 / 4$ \\
\hline 2 & 4 & $2 \cdot 67$ & 208 & 182 & $0 / 3$ & $3 / 4$ & $1 / 4$ & $0 / 4$ \\
\hline 1 & 4 & $4 \cdot 0$ & 214 & 160 & $0 / 4$ & $0 / 3$ & $0 / 4$ & $1 / 4$ \\
\hline 2 & 4 & 4.0 & 258 & 265 & $0 / 3$ & $0 / 4$ & $1 / 4$ & $0 / 4$ \\
\hline 1 & 4 & $6 \cdot 0$ & 294 & 302 & $0 / 4$ & $0 / 4$ & $0 / 4$ & $0 / 4$ \\
\hline 2 & 4 & 6.0 & 314 & 340 & $0 / 4$ & $0 / 4$ & $0 / 4$ & $0 / 4$ \\
\hline 3 & 16 & 3.02 & 177 & 137 & $3 / 15$ & $9 / 14$ & $0 / 15$ & $1 / 15$ \\
\hline 3 & 16 & 3.62 & 207 & 146 & $5 / 16$ & $9 / 16$ & $0 / 16$ & $0 / 16$ \\
\hline 3 & 16 & $4 \cdot 34$ & 224 & 154 & $0 / 16$ & $12 / 16$ & $0 / 16$ & $0 / 16$ \\
\hline 3 & 16 & $5 \cdot 21$ & 281 & 202 & $0 / 16$ & $3 / 16$ & $0 / 16$ & $0 / 16$ \\
\hline \multirow[t]{2}{*}{3} & 16 & $6 \cdot 25$ & 281 & 233 & $0 / 15$ & $0 / 16$ & $0 / 15$ & $0 / 16$ \\
\hline & & & \multirow{4}{*}{\multicolumn{2}{|c|}{$\begin{array}{c}\text { Standard error of } \\
\text { differences of means } \\
\text { (df) } \\
15.0(10) \\
12.8(11) \\
11.9(30)\end{array}$}} & & & & \\
\hline 1 & & & & & & & & \\
\hline 2 & & & & & & & & \\
\hline 3 & & & & & & & & \\
\hline
\end{tabular}

levels of CaPa supplementation in Expts 1 and 2. On diets containing low doses of $\mathrm{CaPa}$ the incidence of deficiency signs was much greater among the CV birds, and the mortality generally higher. The differences were less apparent at levels of supplementation of 4.0 or more $\mathrm{mg} \mathrm{CaPa} / \mathrm{kg}$ diet.

\section{Liver content of $\mathrm{PaA}$}

The results from Expt 3 are recorded in Table 2. The total PaA content of whole livers was significantly higher $(P<0.001)$ in the GF chicks and so was that of bound $\mathrm{PaA}(P<0.05)$. This effect was due to the larger livers of the GF chicks, which had grown more than their corresponding CV controls. When liver weight was calculated in terms of metabolic body-weight $\left(\mathrm{BW}^{0.75}\right)$ the difference between the two environments disappeared. Similarly, when the contents of total and bound PaA were calculated per $\mathrm{g}$ liver there were no differences between the values for GF or CV chicks.

\section{Response to graded doses of $\mathrm{CaPa}$}

In Fig. 1 (Expt 3) the mean body-weights of groups of chicks in the two environments are plotted $v$. dose of dietary $\mathrm{CaPa}$ on a logarithmic scale. The response of the GF chicks was consistently higher than that of their $\mathrm{CV}$ counterparts, and the value for the requirement for PaA of GF: requirement of CV chicks was 62:100. This was deduced from the calculation that the response in $\mathrm{CV}$ chicks produced by, for example, $4.34 \mathrm{mg} \mathrm{CaPa} / \mathrm{kg}$ diet 
Table 2. Expt 3. Liver weights and contents of total and bound pantothenic acid $(P a A)$ in livers of germ-free (GF) and conventional $(C V)$ chicks given suboptimal amounts of dietary calcium pantothenate $(\mathrm{CaPa})$ for the first $21 \mathrm{~d}$ of life

(Mean values for sixteen birds/treatment)

\begin{tabular}{|c|c|c|c|c|c|c|c|}
\hline \multirow{2}{*}{$\begin{array}{c}\text { Dose of } \\
\text { CaPa } \\
\text { (mg/kg diet) }\end{array}$} & \multirow{2}{*}{$\begin{array}{l}\text { Environ- } \\
\text { ment }\end{array}$} & \multicolumn{2}{|c|}{ Liver wt } & \multicolumn{2}{|c|}{$\begin{array}{c}\text { PaA in whole liver } \\
(\mathrm{nm})\end{array}$} & \multicolumn{2}{|c|}{$\begin{array}{c}\mathrm{PaA} \text { concentration in } \\
\text { liver }(\mathrm{nm} / \mathrm{g})\end{array}$} \\
\hline & & $\mathbf{g}$ & BW $^{-75}$ & Total & Bound & Total & Bound \\
\hline 3.02 & $\begin{array}{l}\text { GF } \\
\text { CV }\end{array}$ & $\begin{array}{l}5 \cdot 27 \\
4 \cdot 73\end{array}$ & $\begin{array}{l}0-109 \\
0 \cdot 118\end{array}$ & $\begin{array}{l}1569 \\
1241\end{array}$ & $\begin{array}{l}564 \\
469\end{array}$ & $\begin{array}{l}300 \\
264\end{array}$ & $\begin{array}{r}107 \\
99\end{array}$ \\
\hline 3.65 & $\begin{array}{l}\text { GF } \\
\text { CV }\end{array}$ & $\begin{array}{l}6.07 \\
4.81\end{array}$ & $\begin{array}{l}0.111 \\
0.115\end{array}$ & $\begin{array}{l}1870 \\
1246\end{array}$ & $\begin{array}{l}608 \\
368\end{array}$ & $\begin{array}{l}314 \\
260\end{array}$ & $\begin{array}{r}102 \\
79\end{array}$ \\
\hline $4 \cdot 34$ & $\begin{array}{l}\text { GF } \\
\text { CV }\end{array}$ & $\begin{array}{l}6.64 \\
4.96\end{array}$ & $\begin{array}{l}0 \cdot 115 \\
0 \cdot 113\end{array}$ & $\begin{array}{l}1921 \\
1540\end{array}$ & $\begin{array}{l}780 \\
471\end{array}$ & $\begin{array}{l}291 \\
311\end{array}$ & $\begin{array}{r}118 \\
95\end{array}$ \\
\hline $5 \cdot 21$ & $\begin{array}{l}\text { GF } \\
\text { CV }\end{array}$ & $\begin{array}{l}8 \cdot 37 \\
6 \cdot 79\end{array}$ & $\begin{array}{l}0 \cdot 122 \\
0 \cdot 127\end{array}$ & $\begin{array}{l}2177 \\
1984\end{array}$ & $\begin{array}{l}753 \\
679\end{array}$ & $\begin{array}{l}265 \\
293\end{array}$ & $\begin{array}{r}91 \\
100\end{array}$ \\
\hline 6.25 & $\begin{array}{l}\text { GF } \\
\text { CV }\end{array}$ & $\begin{array}{l}8.79 \\
7.15\end{array}$ & $\begin{array}{l}0 \cdot 129 \\
0 \cdot 120\end{array}$ & $\begin{array}{l}2499 \\
2415\end{array}$ & $\begin{array}{l}903 \\
903\end{array}$ & $\begin{array}{l}288 \\
339\end{array}$ & $\begin{array}{l}105 \\
127\end{array}$ \\
\hline $\begin{array}{l}\text { Significance o } \\
\text { Environmer } \\
\text { CaPa } \\
\text { CaPa } \times \text { envi } \\
\text { Standard erro } \\
\text { differences of } \\
\text { (df 30) }\end{array}$ & $\begin{array}{l}\text { effects: } \\
\text { onment } \\
\text { of } \\
\text { means }\end{array}$ & $\begin{array}{l}* * \\
* * * \\
\text { NS } \\
0.55\end{array}$ & $\begin{array}{c}\text { NS } \\
\bullet \\
\text { NS } \\
0.007\end{array}$ & $\begin{array}{l}* * * \\
\text { NS** } \\
86\end{array}$ & $\begin{array}{l}* \\
\text { N*** } \\
114\end{array}$ & $\begin{array}{l}\text { NS } \\
\text { NS } \\
21\end{array}$ & $\begin{array}{r}\text { NS } \\
\text { NS } \\
\text { NS } \\
20\end{array}$ \\
\hline
\end{tabular}

BW, body-weight; NS, not significant.

- $P<0.05, * * P<0.01$, *** $P<0.001$.

Table 3. Expt 4. Weights and cholesterol contents of pairs of adrenal glands from germ-free $(G F)$ and conventional $(C V)$ chicks given suboptimal amounts of dietary calcium pantothenate $(\mathrm{CaPa})$ for the first $25 \mathrm{~d}$ of life

(Mean values for two groups of twelve birds/treatment)

\begin{tabular}{|c|c|c|c|c|c|}
\hline \multirow{2}{*}{$\begin{array}{c}\text { Dose of } \mathrm{CaPa} \\
\text { (mg/kg diet) }\end{array}$} & \multirow[b]{2}{*}{ Environment } & \multirow{2}{*}{$\begin{array}{c}\text { Body-wt } \\
\text { (g) }\end{array}$} & \multicolumn{2}{|c|}{$\begin{array}{l}\text { Wt of pairs of } \\
\text { adrenal glands }\end{array}$} & \multirow{2}{*}{$\begin{array}{l}\text { Total } \\
\text { cholesterol } \\
\text { content of } \\
\text { adrenals } \\
(\mathrm{mg})\end{array}$} \\
\hline & & & mg & $\mathrm{mg} / \mathbf{k g ~ B W 0 . 7 6}$ & \\
\hline $2 \cdot 67$ & $\begin{array}{l}\text { GF } \\
\text { CV }\end{array}$ & $\begin{array}{l}167 \\
132\end{array}$ & $\begin{array}{l}35.3 \\
30.8\end{array}$ & $\begin{array}{l}763 \\
798\end{array}$ & $\begin{array}{l}0.397 \\
0.330\end{array}$ \\
\hline $4 \cdot 0$ & $\begin{array}{l}\text { GF } \\
\text { CV }\end{array}$ & $\begin{array}{l}240 \\
170\end{array}$ & $\begin{array}{l}36.5 \\
33.4\end{array}$ & $\begin{array}{l}598 \\
713\end{array}$ & $\begin{array}{l}0.612 \\
0.480\end{array}$ \\
\hline \multicolumn{6}{|c|}{ Significance of effects: } \\
\hline Environment & & $* * *$ & $*$ & $\bullet$ & $*$ \\
\hline $\mathrm{CaPa}$ & & $* * *$ & NS & *** & $* * *$ \\
\hline $\begin{array}{l}\text { Standard error } \\
\text { differences of } \\
\text { (df 20) }\end{array}$ & & 7 & 1.8 & 42 & 0.39 \\
\hline
\end{tabular}

BW, body-weight; NS, not significant.

- $P<0.05, * * P<0.01, * * * P<0.001$. 


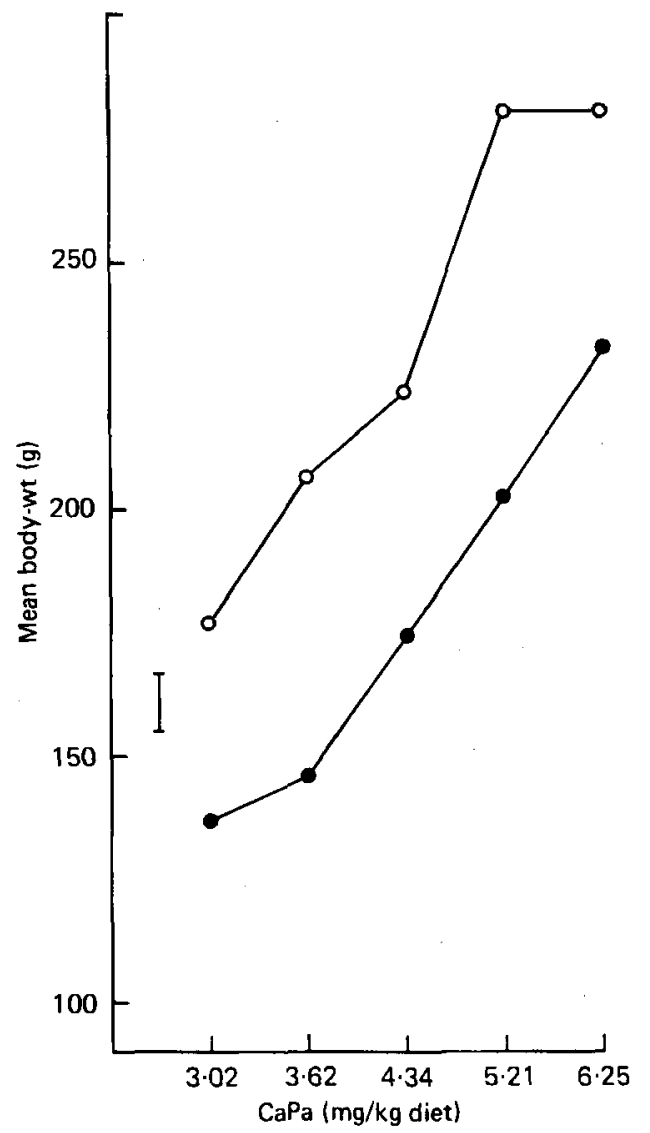

Fig. 1. Mean body-weights of germ-free (GF; $\mathrm{O}-\mathrm{O}$ ) and conventional (CV; -0$)$ chicks reared to $21 \mathrm{~d}$ on different dietary supplements of calcium pantothenate (CaPa). Points represent mean values for sixteen chicks and the vertical bar represents the pooled standard error of differences of means.

was attained with only $2.69 \mathrm{mg} \mathrm{CaPa} / \mathrm{kg}$, with limits of error of $2.28-3.17 \mathrm{mg} \mathrm{CaPa} / \mathrm{kg}$, in GF chicks. The results of Expt 4 lend support to these values. On that occasion the PaA requirement of GF: requirement of $\mathrm{CV}$ chicks was $68: 100$, but as the response curves were each based on two points only, and did not pass the test for parallelism, no limits of error could be calculated.

\section{Effects on the adrenal glands}

Table 3 shows that the adrenal glands from $\mathrm{CV}$ birds were significantly larger than those of the equivalent GF birds, in terms both of actual weight $(P<0.01)$ or as a proportion of metabolic body-weight $(P<0.05)$. The adrenal weights in both environments were significantly affected by the dose of $\mathrm{CaPa}$, being larger at the lower levels of supplementation. The total cholesterol content of the adrenals was significantly less in CV chicks, and in both environments increased with increasing doses of $\mathrm{CaPa}$.

\section{Effects of ACTH on CV chicks}

Results from Expt 5 are given in Table 4. There was a small non-significant depression in body-weights of the birds injected with ACTH. Their adrenals were heavier and the content of cholesterol lower $(P<0.05)$. Neither factor was affected by the dose of $\mathrm{CaPa}$. 
Table 4. Expt 5. Weights and cholesterol contents of pairs of adrenals from conventional chicks given suboptimal amounts of dietary calcium pantothenate $(\mathrm{CaPa})$ for the first $25 \mathrm{~d}$ of life, with or without injections of adrenocorticotrophic hormone (ACTH)

(Mean values for two groups of ten birds/treatment)

\begin{tabular}{|c|c|c|c|c|c|}
\hline \multirow{2}{*}{$\begin{array}{c}\text { Dose of } \mathrm{CaPa} \\
(\mathrm{mg} / \mathrm{kg} \text { diet) }\end{array}$} & \multirow[b]{2}{*}{ ACTH } & \multirow{2}{*}{$\begin{array}{c}\text { Body-wt } \\
\text { (g) }\end{array}$} & \multicolumn{2}{|c|}{$\begin{array}{l}\text { Weight of pairs of } \\
\text { adrenal glands }\end{array}$} & \multirow{2}{*}{$\begin{array}{l}\text { Total } \\
\text { cholestero } \\
\text { content of } \\
\text { adrenals } \\
\text { (mg) }\end{array}$} \\
\hline & & & mg & $\mathrm{mg} / \mathrm{kg} \mathrm{BW} W^{0-75}$ & \\
\hline 2.67 & $\begin{array}{l}0 \\
+\end{array}$ & $\begin{array}{l}193 \\
182\end{array}$ & $\begin{array}{l}32 \cdot 7 \\
36 \cdot 0\end{array}$ & $\begin{array}{l}638 \\
734\end{array}$ & $\begin{array}{l}588 \\
335\end{array}$ \\
\hline $4 \cdot 0$ & $\begin{array}{l}0 \\
+\end{array}$ & $\begin{array}{l}240 \\
202\end{array}$ & $\begin{array}{l}33 \cdot 2 \\
39 \cdot 4\end{array}$ & $\begin{array}{l}549 \\
738\end{array}$ & $\begin{array}{l}589 \\
413\end{array}$ \\
\hline $\begin{array}{l}\text { Significance of effects: } \\
\text { ACTH } \\
\text { CaPa } \\
\text { ACTH } \times \text { CaPa } \\
\text { Standard error of } \\
\text { differences of means } \\
\text { (df 4) }\end{array}$ & & $\begin{array}{c}\text { NS } \\
0 \cdot 05 \\
\text { NS } \\
16\end{array}$ & $\begin{array}{c}\bullet \\
\text { NS } \\
\text { NS } \\
2 \cdot 3\end{array}$ & $\begin{array}{r}* \\
\text { NS } \\
\text { NS } \\
78\end{array}$ & $\begin{array}{l}* \\
\text { NS } \\
\text { NS } \\
103\end{array}$ \\
\hline
\end{tabular}

BW, body-weight; NS, not significant.

$* P<0.05$.

\section{DISCUSSION}

In the four experiments done to compare the chick's response in a GF or CV environment to suboptimal amounts of dietary PaA the body-weights attained by the GF birds were almost always significantly greater than those of their CV counterparts. Several authors using a variety of diets have observed that GF chicks grow better than their CV controls. In the present experiments the poorer growth was not merely a general response to the presence of a gut microflora but was apparently also due to a greater demand for $\mathrm{PaA}$, since the clinical signs of deficiency were more prevalent and more severe in the CV chicks. When growth response curves to graded doses of $\mathrm{CaPa}$ in the two environments were constructed a quantitative estimate could be made which showed that GF chicks needed approximately two-thirds of the dose required by their CV controls to achieve comparable bodyweights and freedom from signs of deficiency.

In earlier work (Coates et al. 1968) GF birds deprived of PaA had a higher content of $\mathrm{PaA}$ in the liver than did their $\mathrm{CV}$ controls. In both environments the liver contained relatively high amounts of the vitamin, even in birds showing severe signs of deficiency. Similar observations were made in Expt 3 now reported. Except at the highest rate of dietary supplementation with $\mathrm{CaPa}$ the amounts both of total and bound $\mathrm{PaA}$ in whole livers were greater in GF than in CV birds. However, this effect was entirely due to the greater weight of liver in the GF birds, which in turn was a function of the increased body-weight. Similarly an increase in the dietary supply of $\mathrm{CaPa}$ brought about an increase in body-weight, liver weight and hence in $\mathrm{PaA}$ content of the liver, but neither the environment nor the dietary supplement of $\mathrm{CaPa}$ had any effect on concentration of $\mathrm{PaA}$ in the liver, which remained fairly constant even in severely deficient chicks. Thus it appears that liver concentration of $\mathrm{PaA}$ is not an indicator of $\mathrm{PaA}$ status, and it is perhaps not surprising that little difference was found between GF and CV chicks in this respect.

The meaning of the term 'stress' is a matter of controversy, as discussed by Freeman 
(1971), who defined the condition in terms of the complex changes that occur in plasma or adrenal constituents following an adverse stimulus. Accepted indicators of stress in the chicken include increased adrenal weight, depletion of adrenal cholesterol and elevation of plasma corticosterone. Only the first two factors were measured in our experiments. The third was considered unreliable in the circumstances, since the level of circulating corticosterone can respond rapidly to a sudden stimulus such as might be imposed while taking blood samples in the restricted conditions of the GF isolators. The CV chicks had significantly heavier adrenal glands with significantly lower contents of cholesterol, so by both criteria they were deemed to be under greater stress, as defined previously, than were their GF counterparts. Increasing the dietary supply of $\mathrm{CaPa}$ reduced the size of the adrenals and increased their content of cholesterol in both environments, suggesting that deficiency of $\mathrm{PaA}$ was itself a form of stress.

To investigate the possible relationship between $\mathrm{PaA}$ status and stress the condition was deliberately induced by injection of ACTH in CV chicks maintained on diets containing inadequate $\mathrm{PaA}$. Adrenal weights were increased and cholesterol content decreased in the injected birds, but neither factor was significantly altered by increasing the supplement of $\mathrm{CaPa}$. These results are thus somewhat at variance with those of the previous experiment, in which signs of stress were considerably more marked at the lower dose of dietary $\mathrm{CaPa}$. It is possible that the more spacious housing of the CV chicks used in the last experiment was less stressful than the smaller cages used in the GF and CV comparison, and that the effects of $\mathrm{PaA}$ inadequacy were consequently less marked. Alternatively the condition induced by injection of ACTH may not have been strictly comparable to that imposed by the presence of a microflora. Whatever the reason for the discrepancy, the findings of the last experiment lend no support to the suggestion that stress increases the chick's requirement for $\mathrm{PaA}$, and other explanations for the apparently greater need of the CV chick for dietary $\mathrm{PaA}$ must be considered.

It is possible that part of the dietary vitamin supply is used by gut microorganisms at the expense of the host, but since the difference was observed even on diets containing no $\mathrm{CaPa}$ it seems more likely that tissue reserves of the vitamin are used at a faster rate by CV compared with GF birds. Analogous findings have been reported in mammals with other water-soluble vitamins. For instance, GF guinea-pigs deprived of ascorbic acid lived longer and developed signs of scurvy later than did their CV counterparts (Levenson et al. 1962) and a greater need for thiamin was shown by CV compared with GF rats (Wostmann et al. 1963). In the presence of microorganisms it might be expected that the need to metabolize end-products of microbial activity would increase the host's metabolic burden and so create a greater demand for the vitamin co-factors concerned in the appropriate pathways. Since CoA plays a role in many biochemical reactions it is not unlikely that the host's requirement for $\mathrm{PaA}$ would be increased in this way.

The authors wish to record their thanks to their colleagues Dr D. Hewitt for advice on the statistical interpretation of the data, Mr J. P. Fordham for management of the germ-free chicks and Dr J. E. Ford for use of facilities for microbiological assays. 


\section{REFERENCES}

Barton-Wright, E. C. (1963). Laboratory Practice. London: United Trade Press.

Bird, O. D. (1963). In Analytical Microbiology, p. 497 [F. Kavanagh, editor]. New York and London: Academic Press.

British Standards Institution (1940). Stand. Specif. Br. Stand. Inst. no. 911.

Coates, M. E., Ford, J. E. \& Harrison, G. F. (1968). Br. J. Nutr. 22, 493.

Coates, M. E., Kon, S. K. \& Shepheard, E. E. (1950). Br. J. Nutr. 4, 203.

Freeman, B. M. (1971). Wld's Poult. Sci. J. 27, 263.

Harrison, G. F. (1969). Lab. Anim. 3, 51.

Levenson, S. M., Tennant, B., Geever, E., Laundy, R. \& Daft, F. S. (1962). Arch int. Med. 110, 693.

Wostmann, B. S., Knight, P. L., Keeley, L. L. \& Kan, D. F. (1963). Fedn Proc. Fedn Am Socs exp. Biol. $22,120$.

Zlatkis, A., Zak, B., Boyle, E. J. \& Mich, D. (1953). J. Lab. clin. Med. 41, 486. 